\title{
Human Security Concept: A New Paradigm in Human Development
}

\author{
Rasheed Mohamed Kutty* \\ Department of Management and Science, Razak School of Engineering and Advanced Technology, Universiti Teknologi Malaysia, 81310 UTM Johor Bahru, \\ Johor, Malaysia \\ *Corresponding author: rasheed@utm.my
}

\begin{abstract}
United Nations (UN) in 1994 under the Human Development Report has chosen a term that can lead to human security, which refers to an integration in human development and is associated with human life good. Generally human security is defined as freedom from fear, and freedom from want. Under this human security is divided into seven categories of safety, economy, food, health, environmental, personal, community and political. These reports are available through the importance of food security as it is placed under the UN human security. Break the traditional concept of human security in which it does not see the country in terms of security simply preferred the military aspect but it is more focused on the aspects of human security itself. This aspect of human security if not given serious concentration it could threaten national security and thus the stability of the region and globally. Thus, the concept of human security and well-being of human happiness is to be the main topic in the discussion of which in the end he is not talking about the country as a whole individual. Furthermore this human security concept will be a new paradigm in human development.
\end{abstract}

Keywords: Human security; human development; human right

(C) 2016 Penerbit UTM Press. All rights reserved

\subsection{INTRODUCTION}

The first Human Development Report in 1990 opened with the simply stated premise that has guided all subsequent Reports: "People are the real wealth of a nation." By backing up this assertion with an abundance of empirical data and a new way of thinking about and measuring development, the Human Development Report has had a profound impact on policies around the world. "The basic purpose of development is to enlarge people's choices. In principle, these choices can be infinite and can change over time. People often value achievements that do not show up at all, or not immediately, in income or growth figures: greater access to knowledge, better nutrition and health services, more secure livelihoods, security against crime and physical violence, satisfying leisure hours, political and cultural freedoms and sense of participation in community activities. The objective of development is to create an enabling environment for people to enjoy long, healthy and creative lives." "Human development, as an approach, is concerned with what I take to be the basic development idea: namely, advancing the richness of human life, rather than the richness of the economy in which human beings live, which is only a part of it." (Human Development Report 2015).

\subsection{HUMAN SECURITY CONCEPT}

Human nature naturally believe they have certain rights that can not be interrupted-destroyed by anyone. This fact is reinforced that the human right to life, practicing free religion, free expression, freedom of movement, equal treatment regardless of color, race, religion and gender (Norraihan Zakaria: 2005). When questioned on the right or happens oppression, people absolutely believe that they are entitled to receive justice and appropriate action should be taken to the human rights violators. The question of human rights will only be formed when humans began to live in a community because of the interaction or relationships with other people in a group of people can trigger discord, strife and various other scenarios. Concerns over the outbreak of this chaotic situation that prompted humanitarian values are formed when the rights and obligations of individuals outlined the sake of social harmony. Human rights are not only acts as a mechanism that protects but also become a very important tool to the development of mankind (Norraihan Zakaria 2005: xvi).

First and Second World Wars in the 19th century could not prevent aggression and human rights violations. Countries such as Britain, France and the Netherlands, Portugal and the United States to act more aggressive in expanding their empire to ignore all these humanitarian values. Following the events of the world began to realize the need for an international organization in place to prevent war and subsequently became mediation or discussion to protect universal human rights. As a result of negotiations between the world's four major powers (United States, Britain, Russia and China), the United Nations (UN) was established in 1945. Three years after the establishment of the United Nations, in 1948 the Universal Declaration of Human Rights was established. Through this declaration was the beginning of the concept of universalism that is a concept that highlights that human rights are the same for all regardless of race, culture and the country began to gain attention of the world (Norraihan Zakaria 2005: xvii). 
This is the sequence of events began to alert the world community and embrace the concept of being able to realize their rights in more detail. As a result discussions about human rights that finally menjurusnya rise to the concept of human security has been released by the United Nations Development Programme (UNDP) in 1994. According to the UNDP concept of human security means:

The security of people through development, not arms; through cooperation, not confrontation; through peace not war...Safety from the constant threats of hunger, disease, crime and repression and protection from sudden and hurtful disruptions to the patterns of our daily lives - whether in the home, in our jobs, in our communities or in our environment. Such threats can exists at all levels of national income and development (UNDP 1994: 6 \& 23).

According to Till Kotter, (2007: 44) since the publication of the UNDP report in 1994, the concept of human security has challenged the security sector towards a more open debate than the previous definition more specific reference to national security. For Anuradha (2005:167), he considers the concept of human security is to emphasize to all human rights with the need for security. Meanwhile, human security emphasizes freedom from fear, freedom from want and where they are in terms of human lives free from fear and free from any requirements that will bring happiness (Llan Zvi Baron: 2008). Even the 1994 UNDP report also clearly stated human security is not a concern with weapons-it is a concern with human life and Dignity (Kanti Bajpai 2003: 202). The existence of the concept of human security has brought a lot of debate and definition dikeutarakan by leaders in this field.

For Kanti Bajpai (2003), human security refers to personal security, free from threats of violence either directly or indirectly. Improvement in human development and good government, and when necessary the use of sanctions or military to achieve human security. Countries, international organizations, non-governmental and other civil society groups in an integrated manner is essential to the integrity of human security. Meanwhile, Louise Frechette (1999) defines human security is more straightforward of all things loved by men and women in this world, enough to feed a family, have a place to live, good health, a school for children, control of terrorism and countries that do not suppress people but rule by consent. For Shachiko Ishikawa (2006) about human security, means to protect the fundamental interests of all human beings to expand human freedom and desire. It is also open to a system that allows people to build resilience in the struggle, dignity and right to life. Meanwhile, for Buzan was military security is not something that often threaten human in daily life issues while security threats such as political, economic, community and environmental issues is what becomes important. Next he adds in the world is now national security concerns should be seen from the general systemic security problem in which individuals, nations and the whole system's role is to ensure the economic, community and environmental factors may be as important as the political and military aspects (Sheehan 2006: 47).

Anne Hammerstad (2000: 395) explains human security is to achieve the social, political, environmental and economic conditions conducive to a free and dignified life to an individual. Gasper argues further discussion on the concept of human security focuses on three main aspects, namely:

First, a focus on basic needs. Second, more specifically, an insistence on basic rights for all. This strengthens the focus on individuals, compared to in the human needs and human development traditions. And lastly, a concern stability as well as average levels of important freedoms (2008: 8).

For Kofi Annan (2000) is more security to a situation that does not involve violence, in line with human rights, good governance, access to education and health. All this according to him is the direction for reducing poverty, achieving economic growth and preventing conflict. Meanwhile, the network also identifies human security human security as:

A humane world where people can live in security and dignity, free from poverty and despair, is still a dream for many and should be enjoyed by all. In such a world, every individual would guaranteed freedom from fear and freedom from want, with an equal opportunity to fully developed their human potential. Building human security is essential to achieving this goal. In essence, human security means freedom from pervasive threats to people's rights, their safety or even their lives.

UNDP report (1994) has outlined seven values that characteristics of human security is threatened. Seven threats are:

1. Threat to economic security (economic security), such as low productivity and high wage costs, job uncertainty and lack of security management.

2. Threat to food security (food security), the lack of food in the country, including the lack of access to food, employment, and fixed income.

3. Threats to health security (health security), which is infectious and parasitic diseases, and cancers of the digestive system diseases, lack of clean water, air pollution and lack of access to good health facilities.

4. Threat to the safety of the environment (environmental security), such as lack of water resources, water pollution, lack of fertile soil, deforestation, pollution and natural disasters.

5. Threats to personal safety (personal security), such as violent crimes, drug trafficking, corruption and terrorism penganaiyaan to children and women.

6. Threat to public safety (security community), such as domestic abuse, cultural and linguistic traditions of fall and ethnic discrimination and discord, murder and genocide.

7. Threat to political security (political security), as an oppressive government, human rights violence and systematic form of military government (UNDP 1994). 


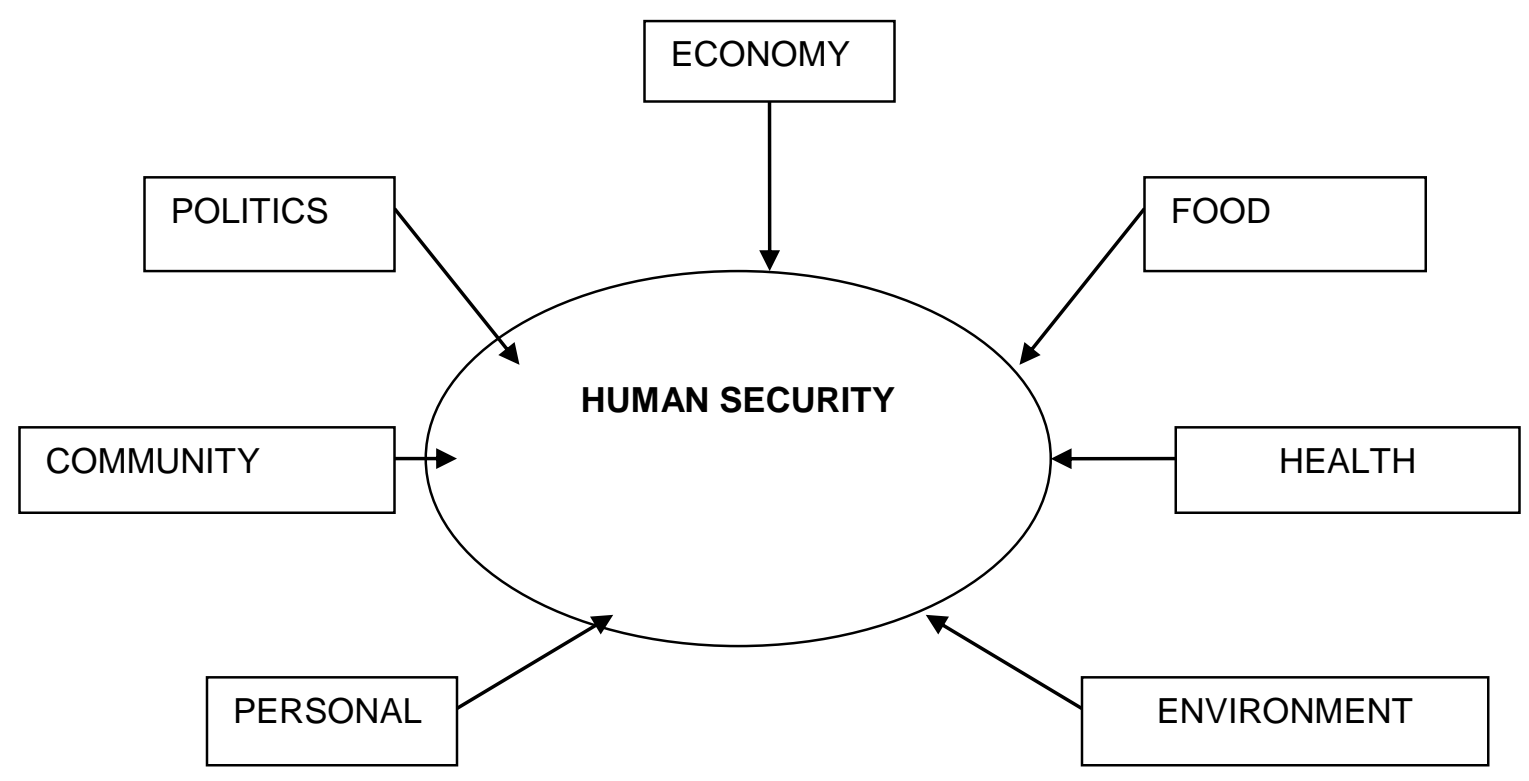

Figure 1 Seven features of forming human security concept Source: Adapted by the author, 2008.

The Figure 1 above shows how the seven features forms human security concept. In addition to the seven threats to human security in the UNDP report also lists six additional feature of a global or transnational threats that are more comprehensive. Six threat are:

1. World population growth put pressure on increasingly scarce land resources and this in turn leads to global poverty, environmental degradation and international migration.

2. The growth of income inequality at the global level that causes excessive consumption and excessive production in the industrialized countries as well as poverty and environmental degradation in developing countries.

3. The addition of international migration due to increasing population, poverty and policies in industrialized countries has resulted in the flow of foreign labor and the increase in foreign refugees.

4. As a result of environmental changes (environment such as acid rain, skin cancer and global warming), decreasing biodiversity, destruction of wetlands, marine and forest destruction.

5. Trafficking and the growing global and multinational nature of the industry.

6. International terrorism has evolved from Latin America in 1960 is now a threat to the entire world (UNDP 1994).

The definition given by the UNDP on human security is something much different in securities or security previously only focused on national security alone. If the previous understanding of the national security focus more on the military as border incursions and wars then this perception has now changed to seven threats mentioned above. Based on this understanding of human security actually focus or advance the quality of human life from the country. If people are not safe then it could eventually threaten the security of the country (Sity David \& Zarina Othman 2005:190). Marry Farrel opinion can strengten this argument:

For too long, the concept of security has been shaped by the potential conflict between states. For too long, security has been equated with threats to a country's borders. For too long, nations have sought arms to protect their security. For most people today, a feeling of insecurity arises more from worries about daily life than from the dread of a cataclysmic world event. Job security, income security, health security, environmental security, security of crime, these are the emerging concerns of human security all over the world (Farrell 2005: 108).

Next statement above is strengthened by Tony Evans (2005: 1) in which he said human security actually give a condition for man to practice and expand their options and the ability of future threatened by them. While military security threats happen to see the country from the outside but is more focused on human security to human security as a whole, particularly on the needs strong economic, social and political stability of a more dignified human life (2005: 1). While Kofi Annan for human security can not be disamaertikan with military concept but it should focus on economic development, social justice, environmental protection, democratization, arms reduction and respect for human rights and the rule of the law. This issue has also received attention in the United Nations and NATO is aware of the world body's security issues they believe all this is not right.

International organizations such as the United Nations and NATO now also operate with a definition of security that is multisectoral and embraces the broader agenda, and not just the military dimensions. This represents a major change from earlier decades where the emphasis was on force projection, deterrence, and the maintenance of the balance of power. This reflects an increasing recognition by bodies such as the UN that, while the focus on military power during the cold war was understandable, 
by defining security in purely military terms and giving it privileged status as "high politics", there was a massive failure to address human suffering in others areas, such as poverty, and a failure to counter environmental degradation (Sheehan 2006: 3 ).

Meanwhile, Mahbub ul Haq, who was a well known figure in the field of human security, he considers human security is not about states and regulation, but about individuals and people (Kanti Bajpai: 2003). He thinks the world is now entering a new era in human security where security will change the whole meaning. In this new concept of security according to Haq is we need to fashion a new concept of human security that's is reflected in the lives of our people, not in the weapons of our country (Kanti Bajpai: 2003). Haq basically ignore the purpose of this tradition that emphasizes safety factor boundary integrity or independence of a country as a fundamental value that must be defended. For him human security brings greater meaning in which it is seen to collective security in terms of benefits to the human or anywhere at home, in work, in the settlements, the community or in their environment.

\subsection{CONCLUSION}

Human security concept brought a new paradigm for human resource development holistically and in total. This concept has placed human resource as one of the vital elements that focuses on human security as a key success and development of the country. This concept has brought a drastic change towards human thinking/knowledge pertaining the importance of human security which should be emphasized compared to security of the country. Therefore, opinion that claimed security of a country is more importance than human security can be viewed as obsolete and outdated. In this new world, every country need to give an emphasize on welfare to its citizens. Furthermore, dynamism of a country will be able to ensure its balance development in terms of economy policy; food; health; environment; personalizes; society; and political which guaranteed the security of a country. If these can be achieved, every citizens in the country will feel benefited as their security are strongly guaranteed. Nevertheless, human security concept not totally reject the role of country security which mainly directed towards defence or arm forces.

\section{References}

Annan, Kofi. (2000). Report of the secretary-general on the work of the organization. General assembly official reports fifty-fifth session supplement No.1(A/55/1). http://www.un.org/documents/sg/reports00/a551e.pdf [20 Jun 2007].

Anne Hammerstad. (2000). Whose security? UNHCR, refuge protection and state security after the cold war. Security dialogue.

Bajpai, Kanti. (2003). The idea of human security. Journal of International Studies, 40(3), 195-228. New Delhi: Sage Publications.

Centre For Unconventional Security Affairs. (2007). Human Security. File://F:/Human Security.htm. [11 April 2007].

GARNET working paper: No 28/08. http://www.iss.ni/content/download/9235/87749/file/Gasper_jolly workshop.pdf. [05 Februari 2009].

Human security Network. (1999). A perspective on human security. http://www.humansecuritynetwork.org./menu-e.phd. [28 Jun 2008].

IFPRI. (2004). Africa Implementing a Human Rights Approach to Food Security. Washington: IFPRI.

Kotler, Till. (2007). Fostering human security through active engagement of civil society actors. Human Security Journal 4, 44-55.

Llan Zvi Baron. (2008). The Human Security Concept, And A Critique. http://www.ipb.org/warfare [13 Jun 2008].

Morgenthau, Hans J. (2006). Ed. Ke-7. Politics Among Nations the Struggle for Power and Peace. New York: McGraw Hill/Irwin.

Norraihan Zakaria. (2005). Konsep Hak Asasi Manusia. Kuala Lumpur: Dewan Bahasa dan Pustaka.

Rosenbloom D. H. (1998). Public Administration Understanding Management, Politics, and Law in the Public Sector. Ed. ke-4. New York: The McGraw-Hill Companies, Inc.

Sen, Amartya (1981). Poverty and Famines: An Essay on Entitlement and Deprivation. New York: Oxford University Press.

Sheehan, Michael. (2006). International Security an Analytical Survey. USA: Lynne Rienner Publishers, Inc. 